\title{
Analisis Pemahaman Siswa Tentang Momen Inersia pada Siswa Kelas XI SMA Negeri 1 Biromaru
}

\author{
Kevin Moris Saripah, Unggul Wahyono, dan Muhammad Ali
}

Email: kevinmoriss@yahoo.com

Program Studi Pendidikan Fisika, Jurusan Pendidikan MIPA, Universitas Tadulako, Jl. Soekarno Hatta KM. 9 Kampus Bumi Tadulako Tondo Palu - Sulawesi Tengah

\begin{abstract}
Abstrak- Penelitian ini bertujuan untuk menganalisis pemahaman siswa tentang momen inersia pada siswa kelas XI SMA Negeri 1 Biromaru. Responden dalam penelitian ini berjumlah 12 siswa kelas XI IPA Model pada SMA Negeri 1 Biromaru yang telah mengikuti materi Dinamika Rotasi. Data dikumpulkan melalui pemberian tes kepada 25 siswa dan wawancara dengan 12 responden untuk ditelusuri secara lebih mendalam kesalahan pemahaman siswa. Data penelitian dianalisis dengan pendekatan kualitatif-deskriptif. Hasil penelitian menunjukkan bahwa pemahaman siswa berada dalam kategori rendah menurut standar yang ditetapkan oleh departemen pendidikan dan kebudayaan. Pemahaman siswa mengenai konsep tentang momen inersia tergolong rendah. Untuk itu pengajar perlu mengajarkan dan membimbing siswa agar dapat memahami konsep dengan baik dan benar dengan cara membuat soal yang berhubungan dengan pemahaman konsep serta menggunakan tampilan animasi powerpoint, foto, gambar, alat peraga dan video.
\end{abstract}

Kata Kunci: Pemahaman, momen inersia.

\section{PENDAHULUAN}

Kemampuan seorang untuk memahami dan menyerap pelajaran sudah pasti berbeda tingkatnya. Ada yang cepat, sedang dan ada pula yang sangat lambat, karenanya mereka seringkali harus menempuh cara berbeda untuk bisa memahami sebuah informasi atau pelajaran yang sama.

Fisika dibangun berdasarkan pengalaman empiris, dimana konsep-konsep diformulasikan berdasarkan fakta dan data hasil pengamatan terhadap gejala, baik gejala ilmiah maupun yang dikondisikan. Meskipun sebagian dari konsep fisika dibentuk melalui analisis matematis, namun pada akhirnya teori yang dibentuk harus diuji melalui eksperimen, dengan demikian eksperimen yang berkonotasi penelitian merupakan bagian penting dalam fisika [4].

Dalam belajar, unsur pemahaman itu tidak dapat dipisahkan dari unsur-unsur psikologis yang lain, dengan motivasi, konsentrasi dan reaksi maka siswa dapat mengembangkan faktafakta, ide-ide, atau skill. Belajar yang efektif akan menghasilkan pemahaman, pengertian, pengetahuan atau wawasan yang baik. Pemahaman tidak sekedar mengetahui, tetapi juga menghendaki agar siswa dapat memanfaatkan bahan-bahan yang telah di pahami. Dalam kenyataanya banyak para siswa di sekolah-sekolah yang melupakan unsur pemahaman itu. Contoh yang banyak terjadi misalnya, para pelajar yang belajar pada malam hari menjelang ujian esok harinya. Kegiatan belajar mengajar seperti ini cenderung hanya sekedar mengetahui isi materi yang di tuangkan dikertas ujian pada pagi harinya, tetapi kalau ditanya dua atau tiga hari kemudian mengenai apa yang di pelajari, kebanyakan siwa sudah lupa. Hal ini menunjukkan para siswa tidak memiliki pemahaman yang kuat untuk menerapkan materi-materi yang dipelajari ke dalam suatu konsep atau pengertian secara menyeluruh. Perlu di tegaskan bahwa pemahaman itu bersifat dinamis, dengan ini diharapkan, pemahaman akan bersifat kreatif, hal tersebut akan menghasilkan imajinasi dan pikiran yang tenang. Apabila siswa benar-benar memahaminya, maka akan siap memberikan jawaban-jawaban yang pasti atas pertanyaanpertanyaan atau berbagai masalah dalam belajar.

Pencapaian pemahaman siswa dapat dilihat pada waktu proses belajar mengajar. Sebagaimana kegiatan-kegiatan yang lainnya, kegiatan belajar mengajar berupaya untuk mengetahui tingkat keberhasilan pemahaman siswa dalam mencapai tujuan yang diterapkan maka evaluasi hasil belajar memiliki saran berupa ranah-ranah yang terkandung dalam tujuan salah satunya yaitu ranah kognitif. Ranah kognitif berkenaan dengan hasil belajar 
intelektual yang berhubungan dengan ingatan atau pengenalan terhadap pengetahuan dan informasi serta pengembangan keterampilan intelektual. Salah satu penyebab yang utama dari tidak efisiennya cara belajar dan berkomunikasi adalah, bahwa manusia pelupa. Alat-alat audio-visual tidak saja menghasilkan cara belajar yang efektif dalam waktu yang lebih singkat, tetapi apa yang diterima melalui alat alat audio-visual lebih lama dan lebih baik tinggal dalam ingatan (Suleiman, 1988: 18) [6].

Dalam penelitian ini, peneliti menganalisis pemahaman siswa tentang momen inersia dengan memberikan soal tes yang merujuk pada tampilan animasi powerpoint, foto, gambar, alat peraga dan video untuk mendukung soal yang diberikan kepada siswa kelas XI SMA Negeri 1 Biromaru agar mudah memahami soal tentang Momen Inersia.

\section{METODELOGI PENELITIAN}

Penelitian ini menggunakan desain penelitian kualitatif [5], dimana penelitian difokuskan pada satu fenomena saja yaitu hanya menganalisis pemahaman siswa tentang momen inersia.

Dalam penelitian ini digunakan pendekatan "deskriptif kualitatif" [3], dimana penelitian ini memanfaatkan berbagai metode ilmiah.

Setting dalam penelitian ini adalah seluruh siswa SMA Negeri 1 Biromaru yang telah mengikuti materi dinamika rotasi. Saat pengumpulan data, soal tes dibagi kepada siswa dengan merujuk pada tampilan animasi powerpoint, foto, gambar, alat peraga dan video. Responden dalam penelitian ini diambil berdasarkan pada tiga kategori yaitu kategori nilai tinggi, nilai sedang dan nilai rendah sesuai kategorisasi standar yang ditetapkan oleh departemen pendidikan dan kebudayaan. Responden yang diambil berjumlah 12 responden yang terdiri dari 4 responden kategori nilai tinggi, 4 responden kategori nilai sedang dan 4 responden kategori nilai rendah. Hal ini dimaksudkan untuk mengefisienkan waktu yang diberikan oleh pihak sekolah.

Langkah-langkah yang ditempuh dalam pengolahan data ini adalah :

Menghitung nilai kemampuan analisis siswa per butir soal:

$$
A=\frac{x}{n} \times 100
$$

Dengan :

A : nilai kemampuan analisis siswa per butir soal

x : skor kemampuan analisis siswa dari butir soal

$\mathrm{n}$ : jumlah skor butir tiap soal

Menghitung nilai kemampuan analisis siswa untuk keseluruhan soal:

$$
A_{\text {rata }}=\frac{\sum A}{\text { skor maksimal }} \times 100 \ldots \ldots \text {...(2) }
$$

Untuk mengetahui secara tepat tingkat persentase tiap deskriptor digunakan rumus perhitungan sebagai berikut (Arikunto, 2010: 265) [1].

$$
\text { Persentase }=\frac{X}{n} \times 100 \%
$$

Dengan :

$X=$ jumlah skor yang diperoleh siswa tiap deskriptor

$\mathrm{n}=$ jumlah skor total tiap deskriptor

Kemampuan siswa dapat dikelompokkan dalam skala lima berdasarkan teknik kategorisasi standar yang ditetapkan oleh departemen pendidikan dan kebudayaan yaitu:

Tabel 1. Kategorisasi Standar untuk Keterampilan Proses Sains [2].

\begin{tabular}{|c|c|}
\hline Kemampuan & Kriteria \\
\hline $85 \%-100 \%$ & Sangat Tinggi \\
$65 \%-84 \%$ & Tinggi \\
$55 \%-64 \%$ & Sedang \\
$35 \%-54 \%$ & Rendah \\
$<34 \%$ & Sangat Rendah \\
\hline
\end{tabular}

Untuk menentukan responden yang akan diwawancarai dilakukan hal berikut.

Menghitung nilai rata-rata siswa dan standar deviasi digunakan rumus (Arikunto, 2010: 343) [1] sebagai berikut:

$$
\begin{aligned}
& \bar{x}=\frac{\sum X i}{n} \ldots \ldots \ldots \\
& S=\sqrt{\frac{\sum\left(X_{i}-\bar{X}\right)^{2}}{n}}
\end{aligned}
$$

Dengan:

$\bar{x}$ : rata-rata nilai yang diperoleh siswa

$\mathrm{n}$ : banyaknya sampel

$S$ : standar deviasi

Pemilihan responden untuk wawancara berdasarkan pada kategori berikut:

Kategori tinggi, diperoleh dengan rumus:

- $\quad$ Nilai $>\bar{x}+$ SD

Kategori sedang, diperoleh dengan rumus:

- $\bar{x}-\mathrm{SD} \leq$ Nilai $\leq \bar{x}+\mathrm{SD}$ 
ISSN 23383240

Kategori rendah, diperoleh dengan rumus:

$$
\text { - Nilai }<\bar{x}-\text { SD }
$$

\section{HASIL DAN PEMBAHASAN}

Siswa yang mengikuti tes pemahaman berjumlah 25 orang siswa yang telah mengikuti mata pelajaran fisika khususnya materi dinamika rotasi. Untuk lebih mengefisienkan waktu diambil 12 orang siswa sebagai responden untuk selanjutnya dilakukan wawancara.

Data hasil pemberian essay test pada siswa mengenai jumlah skor siswa yang disajikan pada Tabel 2.

Tabel 2. Skor Jawaban Tes

\begin{tabular}{|c|c|c|c|}
\hline No. & Inisial Siswa & Skor & Kategori \\
\hline 1 & Siswa-01 & 80,00 & Tinggi \\
\hline 2 & Siswa-02 & 73,33 & Tinggi \\
\hline 3 & Siswa-03 & 70,00 & Tinggi \\
\hline 4 & Siswa-04 & 66,67 & Tinggi \\
\hline 5 & Siswa-05 & 66,67 & Tinggi \\
\hline 6 & Siswa-06 & 60,00 & Sedang \\
\hline 7 & Siswa-07 & 60,00 & Sedang \\
\hline 8 & Siswa-08 & 60,00 & Sedang \\
\hline 9 & Siswa-09 & 56,67 & Sedang \\
\hline 10 & Siswa-10 & 53,33 & Rendah \\
\hline 11 & Siswa-11 & 50,00 & Rendah \\
\hline 12 & Siswa-12 & 50,00 & Rendah \\
\hline 13 & Siswa-13 & 50,00 & Rendah \\
\hline 14 & Siswa-14 & 46,67 & Rendah \\
\hline 15 & Siswa-15 & 46,67 & Rendah \\
\hline 16 & Siswa-16 & 46,67 & Rendah \\
\hline 17 & Siswa-17 & 46,67 & Rendah \\
\hline 18 & Siswa-18 & 46,67 & Rendah \\
\hline 19 & Siswa-19 & 46,67 & Rendah \\
\hline 20 & Siswa-20 & 46,67 & Rendah \\
\hline 21 & Siswa-21 & 46,67 & Rendah \\
\hline 22 & Siswa-22 & 43,33 & Rendah \\
\hline 23 & Siswa-23 & 40,00 & Rendah \\
\hline 24 & Siswa-24 & 40,00 & Rendah \\
\hline 25 & Siswa-25 & 36,67 & Rendah \\
\hline
\end{tabular}

Skor rata-rata yang diperoleh adalah 53,20 dan nilai standar deviasi adalah 7,18. Berdasarkan jawaban tes dari 25 orang siswa dipilih sebanyak 12 orang siswa sebagai responden yang terdiri dari 4 orang siswa setiap kategori untuk diwawancarai.

Data hasil pemilihan responden yang berjumlah 12 orang siswa untuk diwawancara disajikan pada Tabel 4.2.
Tabel 3. Responden

\begin{tabular}{|c|c|c|c|}
\hline No. & Inisial Siswa & Skor & Kategori \\
\hline 1 & R-01 & 80,00 & Tinggi \\
\hline 2 & R-02 & 73,33 & Tinggi \\
\hline 3 & R-03 & 70,00 & Tinggi \\
\hline 4 & R-04 & 66,67 & Sedang \\
\hline 5 & R-05 & 60,00 & Sedang \\
\hline 6 & R-06 & 60,00 & Sedang \\
\hline 7 & R-07 & 60,00 & Sedang \\
\hline 8 & R-08 & 56,67 & Sedang \\
\hline 9 & R-09 & 46,67 & Rendah \\
\hline 10 & R-10 & 46,67 & Rendah \\
\hline 11 & R-11 & 40,00 & Rendah \\
\hline 12 & R-12 & 40,00 & Rendah \\
\hline
\end{tabular}

Skor rata-rata yang diperoleh adalah 58,33 dan nilai standar deviasi adalah 9,72. Berdasarkan skor rata-rata dan standar deviasi tersebut, data hasil jawaban tes dikelompokkan menjadi tiga kategori yaitu kategori tinggi, kategori sedang dan kategori rendah.

Pengkategorian dilakukan berdasarkan kategorisasi standar yang ditetapkan oleh departemen pendidikan dan kebudayaan [2]. Skor rata-rata yang diperoleh adalah 53,20 dan nilai standar deviasi adalah 7,18 tergolong pada kategori rendah. Pada butir soal nomor 1 nilai rata-rata yang diperoleh responden adalah 50,40 untuk butir soal nomor 2 nilai rata-rata yang diperoleh responden adalah 51,20, untuk butir soal nomor 3 nilai rata-rata yang diperoleh responden adalah 44,80, untuk butir soal nomor 4 nilai rata-rata yang diperoleh responden adalah 48,00 , untuk butir soal nomor 5 nilai rata-rata yang diperoleh responden adalah 46,40, sedangkan untuk butir soal nomor 6 nilai ratarata yang diperoleh responden adalah 78,40. Berdasarkan jawaban tes dari 25 orang siswa dipilih sebanyak 12 orang siswa sebagai responden yang terdiri dari 4 orang siswa setiap kategori untuk diwawancarai.

Penentuan kategori tinggi, kategori sedang dan kategori rendah dilakukan dengan terlebih dahulu menghitung jumlah skor rata-rata dan standar deviasi. Skor rata-rata yang diperoleh adalah 58,33 dan nilai standar deviasi adalah 9,72 tergolong pada kategori sedang. Pada butir soal nomor 1 nilai rata-rata yang diperoleh responden adalah 53,33, untuk butir soal nomor 2 nilai rata-rata yang diperoleh responden adalah 56,67 , untuk butir soal nomor 3 nilai rata-rata yang diperoleh responden adalah 51,67, untuk butir soal nomor 4 nilai rata-rata yang diperoleh 
responden adalah 53,33, untuk butir soal nomor 5 nilai rata-rata yang diperoleh responden adalah 55,00, sedangkan untuk butir soal nomor 6 nilai rata-rata yang diperoleh responden adalah 80,00 . Berdasarkan skor rata-rata dan standar deviasi tersebut, data hasil jawaban tes dikelompokkan menjadi tiga kategori yaitu kategori tinggi, kategori sedang dan kategori rendah.

Berdasarkan distribusi jawaban siswa yakni :

1) Kategori tinggi (Nilai $>\bar{x}+\mathrm{SD}$ ) : R-01, R-02, dan R-03.

2) Kategori sedang $(\bar{x}-\mathrm{SD} \leq$ Nilai $\leq \bar{x}+\mathrm{SD})$ : R-04, R-05, R-06, R-07 dan R-08

3) Kategori rendah (Nilai $<\bar{x}-\mathrm{SD}$ ) : R-09, R-10, R-11 dan R-12.

Wawancara dilakukan pada saat jam pelajaran berlangsung. Wawancara ini dilakukan dengan cara menghadirkan satu orang responden yang akan diwawancarai, namun responden lain tidak mengetahui isi pertanyaan wawancara karena tidak secara bersamaan. Pembagian ini dimaksudkan agar tidak terjadi intervensi jawaban responden. Wawancara ini telah mendapatkan izin dari guru mata pelajaran fisika yang bersangkutan.

Berdasarkan hasil wawancara yang dilakukan, secara umum responden mengaku bahwa mereka lebih mudah menganalisis soal dengan merujuk pada tampilan animasi powerpoint, foto, gambar, alat peraga dan video daripada hanya melihat teks yang ada karena tampilan ini sangat mendukung siswa dalam memahami soal yang diberikan.

Pada soal Nomor 1 tentang seseorang yang memutar beban dalam olahraga fitness, responden yang dapat menjawab tepat serta dapat menjelaskan dengan lengkap hanya ada 1 responden. Kebanyakan responden menjawab tepat serta menjelaskan, namun penjelasan yang diberikan kurang lengkap.

Pada soal Nomor 2 tentang bola menggelinding, tidak ada responden yang dapat menjawab tepat serta dapat menjelaskan dengan lengkap, tetapi ada 6 responden yang menjawab tepat serta menjelaskan, namun penjelasan yang diberikan kurang lengkap.

Pada soal Nomor 3 tentang peloncat indah, tidak ada responden yang dapat menjawab tepat serta dapat menjelaskan dengan lengkap, tetapi ada 4 responden yang menjawab tepat serta menjelaskan, namun penjelasan yang diberikan kurang lengkap.
ISSN 23383240

Pada soal Nomor 4 tentang pemain sirkus, tidak ada responden yang dapat menjawab tepat serta dapat menjelaskan dengan lengkap, tetapi ada 4 responden yang menjawab tepat serta menjelaskan, namun penjelasan yang diberikan kurang lengkap.

Pada soal Nomor 5 tentang penari balet, tidak ada responden yang dapat menjawab tepat serta dapat menjelaskan dengan lengkap, tetapi ada 5 responden yang menjawab tepat serta menjelaskan, namun penjelasan yang diberikan kurang lengkap.

Pada soal Nomor 6 tentang seseorang yang mengangkat ember yang berisi air, tidak ada responden yang dapat menjawab tepat serta dapat menjelaskan dengan lengkap, tetapi semua responden menjawab tepat serta menjelaskan, namun penjelasan yang diberikan kurang lengkap.

Tampilan animasi powerpoint, foto, gambar, alat peraga dan video ini, sangat mendukung siswa dalam mengerjakan tes yang diberikan karena rata-rata siswa sangat mengerti dengan maksud dari isi tes karena mereka bisa langsung melihat secara nyata kegiatan yang berhubungan dengan isi tes tersebut lewat tampilan, baik animasi powerpoint maupun alat peraga yang ditampilkan. Adapun kelemahan dalam memperlihatkan tampilan tersebut, ada sebagian siswa yang hanya melihat tampilan langsung mengerjakan soal yang ada tanpa memikirkan konsep terlebih dahulu.

Berdasarkan hasil wawancara yang dilakukan, secara umum siswa mengaku bahwa memikirkan konsep tentang momen inersia sangat penting dalam memahami soal yang diberikan, tetapi mereka susah untuk memahami soal yang berhubungan dengan pemahaman konsep momen inersia itu sendiri.

\section{KESIMPULAN}

Berdasarkan analisis data penelitian dapat disimpulkan bahwa pemahaman siswa tentang momen inersia pada siswa kelas XI SMA Negeri 1 Biromaru tergolong pada kategori rendah.

Berdasarkan hasil wawancara yang dilakukan, secara umum responden mengaku bahwa mereka merasa sangat penting memikirkan konsep, tetapi mereka susah untuk memahaminya. 


\section{DAFTAR PUSTAKA}

[1]Arikunto, S. (2010). Manajemen Penelitian. Jakarta : Rineka Cipta.

[2]Departemen Pendidikan dan Kebudayaan. (1995). Kamus Besar Bahasa Indonesia. Jakarta : Balai Pustaka.

[3]Moleong, L. J. (2010). Metodologi Penelitian Kualitatif. Bandung : PT Remaja Rosdakarya.

[4]Sudrajad, H. (2009). Pengembangan Perangkat Percobaan Konsep Rotasi untuk Pembelajaran Fisika di SMA dan Universitas. Dalam Jurnal Geliga Sains [Online], Vol 3 (2), 7 Halaman. Tersedia : http://ejournal.unri.ac.id/index.php/JGS/article/view L299 [9 September 2013].

[5]Sukmadinata, N. S. (2011). Metode Penelitian Pendidikan. Bandung : PT. Remaja Rosda Karya.

[6]Suleiman, A. H. (1988). Media Audio - Visual. Jakarta : PT. Gramedia. 